Н.В. Замотаєва, старший викладач кафедри гуманітарної та соціально-економічної підготовки факультету підготовки офіцерів запасу НУОУ імені Івана Черняховського

\title{
АКТИВІЗАЦІЯ САМООСВІТНЬОЇ ПІДГОТОВКИ ВИКЛАДАЧІВ ГУМАНІТАРНИХ ДИСЦИПЛІН ВВНЗ ІЗ ВИКОРИСТАННЯМ КЕЙС- ТЕХНОЛОГІї
}

Стаття присвячена обтрунтуванню наукових підходів до організачії самоосвітньої підготовки викладачів гуманітарних дисциплін вищої військової школи у системі неперервної професійної освіти.

Доведено, щьо використання кейс-технології сприяє поглибленню самоосвітньої компетентності викладачів гуманітарних дисииплін за рахунок виконання різного роду випереджальних завдань (пошук та представлення інформації у мережі Інтернет, створення списку посилань на інформаційні ресурси Інтернет, розробка мультимедійної презентаціï у програмі MS Power Point, використання електронної пошти, обмін повідомленнями у чаті, створення та розміщення інформащії у блозі тощо), сприяє активізації дослідницької діяльності викладачів гуманітарних дисциилін ВВНЗ, створює належні умови для практичного застосування набутих знань під час виконання різного роду завдань творчого характеру.

Ключові слова: самоосвітня підготовка; інтерактивні технології; кейс-технологія; нові інформаційні технологї; портфоліо; викладачі гуманітарних дисииплін; вищі військові навчальні заклади.

\section{Постановка проблеми.}

Професійна підготовка викладачів гуманітарних дисциплін ВВНЗ в умовах модернізації вищої військової освіти, переходу на компетентнісну освітню парадигму потребує посилення технологічності, інтерактивності, інтерсуб'єктності, креативності освітнього процесу, переорієнтації із змістоцентричного на розвивальний, творчий компонент у формуванні освітньо-професійних програм. Особливо актуальною $\epsilon$ проблема технологізації, активізації самоосвітньої підготовки тих, хто навчається, що зумовлює актуальність пропонованої розвідки, іiі теоретичне і практичне значення.

Мета статті - проаналізувати наукові підходи до організації самоосвітньої підготовки викладачів ВВНЗ у процесі неперервної професійної освіти, розкрити особливості активізації самостійної роботи 3 використанням кейс-технології.

Фундаментальні засади обраної проблеми закладено у працях А. Алексюка, А. Вітченка, В. Загвязинського, Н. Мачинської, І. Підкасистого, Г. Селевка, С. Сисоєвої, О. Сидоренка, В. Чуба, О. Сурміна та інших учених.

Аналіз наукових розвідок свідчить про те, що у тлумаченні досліджуваного поняття немає єдиних поглядів. Самоосвітня підготовка розглядається і як засіб організації та виконання тими, хто навчається певної діяльності у відповідності 3 поставленою метою [7, с. 47], i як цілеспрямована, внутрішньо мотивована, структурована самим суб'єктом сукупність дій, що виконуються і корегуються ним у відповідності до процесу і результату діяльності [3, с. 255], і як дієвий інструмент формування 
майбутніх фахівців із високою професійною компетентністю, здатних до самостійного набуття знань, креативності та навчання впродовж усього життя [5, с. 325]. Таким чином, з одного боку, самоосвітня підготовка становить собою вид діяльності, що стимулює самостійність, пізнавальний інтерес, а $з$ іншого - систему заходів, з метою залучення тих, хто навчається, спрямованих на автономне опрацювання спеціально розроблених завдань, що відбувається без безпосередньої участі (присутності) викладача, хоча і скеровується ним.

Згідно 3 поглядами А. Алексюка, самостійність у здобутті знань проявляється лише завдяки власній діяльності, з появою внутрішньої потреби у знаннях, пізнавальних інтересів, захопленості та передбачає оволодіння складними вміннями i навичками бачити зміст та мету роботи, організовувати власну самоосвіту, вміння по-новому підходити до вирішення питань, пізнавальну і розумову активність і самостійність, здатність до творчості [1, с. 433-434]. Провідного значення ця настанова набуває для процесу професійної освіти дорослої людини, яка прагне до більшої самостійності у засвоєнні знань, автономності у прийнятті рішень, відзначається критичним ставленням до репродуктивних прийомів навчання і форм організації навчально-пізнавальної діяльності, посиленим інтересом до життєвого і професійного досвіду тощо.

Система самоосвітньої підготовки викладачів гуманітарних дисциплін ВВН3 реалізується на основі як традиційних загальнодидактичних (науковості, системності, розвивальності, проблемності, наступності, доступності тощо), так і сучасних андрогогічних принципів, серед яких особливо важливого значення набувають такі:

1. Принцип самостійності навчання (тому, хто навчається, належить провідна роль у процесі навчання як за часом, так і за характером діяльності).

2. Принцип опори на досвід учня-дорослого (побутовий, соціальний, професійний досвід того, хто навчається, може бути використаний як в якості джерела власного навчання, так і для навчання інших).

3. Принцип елективності навчання (надання, тому, хто навчається, певної свободи вибору цілей, змісту, форм, методів, джерел, засобів, термінів, часу, місця навчання, оцінювання результатів навчання).

4. Принцип співробітництва (виконання визначених завдань у спільній діяльності) [9, с. 34].

Виклад основного матеріалу дослідження. Окремого значення для налагодження самоосвітньої підготовки військових педагогів у системі формальної (офіційно визнаної, обов'язкової, регламентованої освіти), що реалізується у системі курсової підготовки (перепідготовки), підвищення кваліфікації, педагогічного стажування та неформальної освіти (добровільної, нерегламентованої) набуває принцип інтерактивності. Він спрямований на оволодіння дієвими способами міжособистісної та професійної комунікації, прийомами і засобами ефективного розв'язання фахових проблем у процесі спілкування. Останнє пояснює нагальність 
упровадження інтерактивних технологій, серед яких особливо важливе місце належить технології ситуативного аналізу (кейс-технології).

Завдяки застосуванню кейс-технології той, хто навчається, «самостійно, хоча і спираючись на поради викладача, здобуває знання, які, на його думку, необхідні для вирішення проблеми кейсу» [10, с. 195]. За таких умов змінюється характер самостійної підготовки, внаслідок чого головна увага акцентується на розвитку самоосвітніх умінь військових педагогів, здатності самостійно генерувати варіанти рішення проблемних ситуацій, розв'язувати проблеми на основі попередньо засвоєних знань.

Для успішного виконання завдань у процесі самостійної роботи над кейсами викладачі-гуманітарії повинні виявити вміння планувати власну діяльність, поєднувати пасивні способи навчання (читання, опрацювання джерел, виконання репродуктивних завдань тощо) з активними методами пізнання (постановка проблем, пошук шляхів і прийомів їх вирішення, генерування ідей тощо).

Джерелом ефективної самоосвітньої підготовки під час роботи над кейсами виступає навчально-пізнавальна активність усіх суб'єктів навчання, що забезпечується особистісними (мотиви, прагнення, цінності) та соціальнопедагогічними чинниками (характер взаємовідносин у колективі, творча спрямованість навчання та професійної діяльності тощо).

Серед показників ефективності самоосвітньої діяльності викладачів із кейсами визначили такі:

- здатність планувати власну самостійну діяльність, прогнозувати іiі результати відповідно до поставленої мети;

- володіння належною організаційною культурою, готовність організаційно забезпечити успішне виконання визначених у кейсі завдань без безпосередньої участі викладача;

- сформованість умінь здійснювати систематичний самоконтроль та корегування результатів власної діяльності у процесі опрацювання кейсу.

До найбільш сприятливих умов, що забезпечують активну пізнавальну діяльність педагогів у процесі самостійної підготовки над кейсами, відносимо наступні:

1. Налаштування на продуктивну, творчу, самоорганізовану навчальнопізнавальну діяльність.

2. Налагодження дієвої системи консультування викладачів, забезпечення неперервної інтерактивної комунікації між ними.

3. Урізноманітнення видів і форм завдань для самостійної підготовки, які мають спонукати до самостійного набуття знань та забезпечувати творчий рівень опрацювання кейсів.

Проектувати можливі варіанти розв'язання проблемної ситуації та колективне їх обговорення доцільно проводити за допомогою нових інформаційних технологій (телекомунікаційні засоби, Інтернет, чат тощо).

Використання ресурсів глобальної мережі Інтернет під час самоосвітньої діяльності над кейсами дозволяє викладачам не лише швидко знайти необхідну інформацію, а й відпрацювати власний творчий продукт (варіант 
розв'язки проблемної ситуації, викладеної у «живому» кейсі, моделювання різних шляхів розвитку конфлікту, есе $з$ викладенням подій, що передували проблемній ситуації тощо). Звернення до електронного середовища дозволяє реалізувати одну з головних умов інтерактивного навчання - налагодження міжособистісної взаємодії. Ті, хто навчаються, отримують можливість висловити власні погляди на порушену проблему, обговорити іiі зі своїми колегами під час онлайн-спілкування, обміну думками в чаті та ін.

Електронна співпраця, за визначенням Н. Морзе i Л. ВарченкоТроценко, становить комплекс заходів, спрямованих на підтримку взаємодії між людьми в електронному вигляді за допомогою мережі Інтернет, які разом працюють над розв'язанням спільних завдань [6, с. 94]. До основних складових, які визначають електронну співпрацю, вітчизняні дослідники відносять спільні завдання, визначені ролі для кожного учасника, технології і сервіси електронної співпраці, компетентності, якими володіють особи, що залучаються до співпраці, фізичне (матеріальне), соціальне навколишнє середовище, що оточує залучених осіб [6, с. 97].

Залучення військових педагогів-гуманітаріїв до електронного обговорення під час аналізу проблемної ситуації дозволяє встановити комунікацію у реальному часі не лише 3 одногрупниками та викладачами. Значущість такої форми самостійної роботи для нашого дослідження пояснюється тим, що до спільного виконання завдань вдається залучати викладачів інших ВВНЗ. Це дозволяс підвищити інтерес до навчання, удосконалити навички командної роботи, допомагає суттєво економити час, матеріально-технічні та фінансові ресурси.

Ефективним прийомом залучення викладачів гуманітарних дисциплін ВВНЗ до педагогічної спадщини, використання передового досвіду навчання і виховання молодого покоління вважаємо побудову кейсу на основі уривків iз праць видатних педагогів минулого, що містять складні педагогічні ситуації. Яскравим прикладом цього може слугувати «Педагогічна поема» А. Макаренка, в одному із розділів якої - «Характер і культура» - викладено сповнену драматизму історію становлення педагогічного стилю видатного педагога, засновника системи колективного виховання. Саме цю історію було використано як основу для кейсу «Чому віддати перевагу: педагогічній дії чи педагогічній рефлексії?.

Як відомо, із самого початку своєї педагогічної діяльності в колонії імені Максима Горького А. Макаренко зіштовхнувся із проявами насильства з боку колоністів, які не визнавали ніяких інших аргументів, крім сили. Про ці прикрі обставини йдеться в кейсі, що пропонується для самостійного вивчення.

\section{Ситуація}

Одного вечора до кімнати завідуючого колонією імені Максима Горького, де обговорювались результати роботи за день, увірвався один із колоністів і вигукнув: «-У спальні хлопці ріжуться! 
Я - бігом з кімнати. У спальні содом і крик. У кутку дві групи, які позвірячому визвірилися. Загрозливі жести i наскоки перемішуються із запаморочливою лайкою... <...>

На ліжку, оточеному натовпом співчуваючих, сидить поранений i мовчки перев'язує шматком простирадла порізану руку.

Я ніколи не розбороняв тих, що билися, не намагався їх перекричати.

За моєю спиною Калина Іванович перелякано шепоче:

- Ой, швидше, швидше, голубчику, бо вони ж, паразити, поріжуть один одного...

Але я стою мовчки на дверях і спостерігаю. Поволі хлопці помічають мою присутність й замовкають.

Тиша, що швидко настає, змушує отямитись і найрозлюченіших. Ховаються фінки, і опускаються кулаки, гнівні ...монологи перериваються на півслові. Однак я продовжую мовчати: всередині у мене самого закипає гнів і ненависть до всього цього дикого світу. Це - ненависть безсилля, бо я дуже добре знаю: сьогодні не останній день.

Нарешті у спальні встановлюється моторошна, важка тиша, вщухають навіть глухі звуки напруженого дихання.

Тоді раптом вибухаю я сам, вибухаю і в нападі справжньої злоби і в абсолютно свідомій впевненості, що так треба:

- Ножі на стіл! <...> Обушки! <...> Спати!..

Я не йду із спальні, поки всі не вкладаються» [4, с.203-204].

Поглиблене вивчення вищевикладеної проблемної ситуації передбачає абстрагування від конкретних подій і фактів, зосередження уваги на тій складній внутрішній боротьбі, що відбувається всередині автора «Педагогічної поеми». 3 одного боку, А. Макаренко усвідомлює весь драматизм ситуації, пов'язаної з виникненням загрози здоров'ю та життю вихованців. 3 іншого він добре усвідомлює, що не має права виявити легкодухість, втратити контроль над собою і обставинами, що склалися, знизитись до рівня «темної маси». Саме тому педагог не піддається спокусі негайно втрутитися в конфлікт, знайти i покарати винуватців, а через рефлексію шукає способи впливу на свідомість колоністів. Розуміючи неспроможність одразу вирішити проблемну ситуацію, А. Макаренко доходить висновку про необхідність пробудження у вихованців саморефлексії, щоб кожен 3 них замислився над своїми вчинками, дав їм об'єктивну оцінку, зрозумів усю пагубність насильницьких підходів до вирішення наявних проблем.

3 метою належного спрямування аналітичної роботи над текстом запропонованого кейсу організовується самостійна робота над системою запитань і завдань:

1. Уважно перечитайте пропонований уривок із «Педагогічної поеми» А. Макаренка, знайдіть у ньому ті фрагменти, які відображають його складний емоційний стан.

2. Визначте і схарактеризуйте ті емоції, що охоплюють педагога після повідомлення про бійку та різанину серед колоністів. 
3. Відтворіть плин думок А. Макаренка на шляху до кімнати, де відбувалась бійка.

4. Чому А. Макаренко віддав перевагу не дії, а педагогічній рефлексії, навіюванню?

5. Чи можна кваліфікувати рішення А. Макаренком складної педагогічної ситуації як таке, що властиве прихильнику гуманістичного виховання, як педагогу-майстру? Якщо так або ні, то чому, за якими ознаками? Прокоментуйте поведінку відомого педагога, використовуючи окремі цитати $з$ його «Педагогічної поеми».

На матеріалі педагогічної спадщини А. Макаренка відпрацювали прийом «ланцюгового кейс-стаді», сутність якого полягає у проектуванні тематично пов’язаних між собою кейсів, тобто своєрідного ланцюжка кейсів, 3 яких наступний актуалізує зміст попереднього, поглиблює i розширює раніше набуті знання та вміння, надає поштовх для подальшого розроблення проблемних питань на творчому рівні. Наприклад, опрацьовуючи кейс «Безцінний досвід», присвячений аналізу наявних розроджень в оцінюванні актуальності педагогічної спадщини А. Макаренка для сучасної системи освіти, викладачі отримали завдання проаналізувати увесь спектр поглядів на порушену проблему, порівняти протилежні оціночні судження (С. Максимюк, Ю. Руденко, М. Сметанський) та наукову аргументацію. Крім того, було запропоновано завдання дослідницького характеру:

1. Опрацюйте науково-методичну літературу, запропоновану до кейсу, та 3'ясуйте наявні тенденції щодо використання науково-педагогічної спадщини засновника системи колективного виховання у сучасній освіті.

2. Підготуйте письмовий розбір окремих фрагментів наукових чи художніх текстів, у яких висвітлюються педагогічні ідеї А. Макаренка.

3. Прокоментуйте такі оціночні судження сучасних вітчизняних дослідників про науково-педагогічну спадщину А. Макаренка: «А. Макаренко нерідко реалізує «педагогіку з револьвером», «командирську педагогіку», педагогіку «диктатора», як він сам себе називає», «Домінуючими цінностями науково-методичного i практичного досвіду А. Макаренка є більшовицько-партійні ідеї, антиукраїнські тенденції, наповнення поняття колективу радянським змістом, науково хибні підходи до формування особистості та колективу» [8]; «А. Макаренко більшу роль відводив зовнішнім формам організації впливу: колективу, методиці паралельної діі, педагогічній техніці, створенню та вирішенню конфліктних ситуацій. Він скептично ставився до «парної педагогіки», яка передбачала безпосередній виховний уплив педагога на вихованця, і однозначно віддавав перевагу «педагогіці паралельної дії», прийомам упливу на вихованця через колектив...» [11, с.57]. Чим викликані такі критичні висловлювання? Обгрунтуйте власну думку.

4. Сформулюйте в тезах власні погляди на проблему актуальності науково-педагогічної спадщини А. Макаренка, опублікуйте їх на форумі 3 метою подальшого публічного обговорення. 
На наступному етапі самостійної роботи пропонується виконати завдання, спрямовані на розвиток креативного мислення, творчих здібностей викладачів-гуманітаріїв:

1. Скласти професійний портрет А. Макаренка періоду його педагогічної діяльності в колонії імені Максима Горького. Визначити на основі проаналізованої проблемної ситуації основні особистісні та професійні якості педагога, які в них проявились і забезпечили вирішення конфлікту.

2. Розробити проект інтернет-сторінки «Педагогічна спадщина А. Макаренка у сучасному науковому дискурсі». Сформувати рубрикацію інтернет-сторінки, дібрати змістове наповнення (контент), запропонувати художнє оформлення.

3. Підготувати сценарій заочної екскурсії до меморіального музею А. Макаренка 3 можливістю використання інтернет-навігації, включити до нього відповідний ілюстративний (культурологічний, дидактичний, хрестоматійний) матеріал і коментарі до нього.

Виконання останнього завдання вимагає ретельної підготовки. Перш за все учасники обговорення мають опрацювати рекомендовані джерела, вивчити експонати музею, документи, твори, епістолярій А. Макаренка. На цьому етапі важливо чітко визначити маршрут майбутньої екскурсії, виділити найважливіші об'єкти, відібрати відповідний мультимедійний матеріал (фотографії, ілюстрації, аудіо- та відеозаписи тощо), які допоможуть відтворити основні віхи життєвого і творчого шляху талановитого педагога. Зануритися у минулі часи під час проведення заочної екскурсії слухачам допоможуть фрагменти художнього фільму «Педагогічна поема» (1955, режисери Олексій Маслюков, Мечислава Маєвська).

Висновки. На підставі викладеного матеріалу встановлено, що організована робота над кейсами сприяє активізації самоосвітньої підготовки викладачів гуманітарних дисциплін ВВНЗ шляхом формування у них практичних умінь самостійно добирати та аналізувати теоретичний матеріал, необхідний для вирішення проблеми, оволодіння навичками самоосвіти та самоорганізації у процесі визначення проблеми, аналізу, моделювання шляхів i способів іï розв'язання. Завдяки органічному поєднанню інтерактивних технологій, використанню нових інформаційних технологій під час самостійного опрацювання кейсів підвищується рівень продуктивності навчально-пізнавальної діяльності слухачів, поглиблюється їхня комунікативна компетентність, закладається міцне підгрунтя для інтеграції освітньо-професійної i науково-дослідницької підготовки військового педагога, підвищення інноваційного потенціалу педагогічного пошуку.

Перспективи подальшого розроблення порушеної проблеми вбачаємо у дослідженні ефективних шляхів посилення результативності аудиторної роботи в умовах курсової підготовки та підвищення кваліфікації викладачів гуманітарних дисциплін ВВНЗ. 


\section{ЛІТЕРАТУРА}

1. Алексюк A. М. Педагогіка вищої освіти України : Історія. Теорія : підруч./ А. М. Алексюк. - К. : Либідь, 1998. - 558 с.

2. Вітченко A. О. Технології навчання у вищій військовій школі : теорія i практика : навч.-метод. посіб. / А. О. Вітченко, В. І. Осьодло, С. М. Салкуцан ; за заг. ред. професора В. М. Телелима. — К. : НУОУ ім. Івана Черняховського, 2016. — 250 с.

3. Зимняя И. А. Педагогическая психология. Учебник для вузов. Изд. Второе, доп., испр. и перераб. - М. : Издательская корпорація «Логос», 1999. - 384 с.

4. Макаренко А. С. Собр. соч. : в 4-х т. / А. С. Макаренко. - М. : Правда, 1987. T. 1 : Марш тридцатого года. Педагогическая поэма - 576 с. - (Библиотека «Огонёк». Отечественная классика).

5. Мачинська H.I. Педагогічна освіта магістрантів вищих навчальних закладів непедагогічного профілю: монографія / Н. І. Мачинська ; за ред. С. О. Сисоєвої. — Львів : ЛьвДУВС, 2013. - 416 с.

6. Морзе Н. В. Формування навичок ефективної співпраці студентів під час використання вікі-порталу / Наталія Вікторівна Морзе, Лілія Олександрівна ВарченкоТроценко // Інформаційні технології і засоби навчання. - 2014. — Том 40, — №2. — С. 92-106.

7. Пидкасистый П. И. Самостоятельная деяльность учащихся. Дидактический анализ процесса и структуры воспроизведения и творчества. - М. : Педагогика, 2002, $182 \mathrm{c}$.

8. Руденко Ю. Чи був Антон Макаренко педагогом-гуманістом? / Ю. Руденко // Українське слово. — 2013. — № 36 (4-10 верес.). — С. 12-13.

9. Сисоєва С. О. Інтерактивні технології навчання дорослих : навч.-метод. посіб. / С. О. Сисоєва. — К. : ВД «ЕКМО», 2011. - 320 с.

10. Ситуационная методика обучения: Теория и практика / Сост. А. И. Сидоренко, В. И. Чуба. — К. : Центр инноваций и развития, 2001. — 256 с.

11. Сметанський M.I. Порівняльний аналіз педагогічних ідей А. Макаренка i В. Сухомлинського / М. І. Сметанський // Витоки педагогічної майстерності : зб. наук. праць. Серія : пед. науки. - Полтава : Вид-во ПДПУ ім. В. Г. Короленка, 2008. — Вип. 4. - С. 55-64.

\section{АКТИВИЗАЦИЯ САМООБРАЗОВАТЕЛЬНОЙ ПОДГОТОВКИ ПРЕПОДАВАТЕЛЕЙ ГУМАНИТАРНЫХ ДИСЦИПЛИН ВОЕННОГО ВУЗА С ИСПОЛЬЗОВАНИЕМ КЕЙС-ТЕХНОЛОГИИ}

Статья посвящена обоснованию научных подходов $\kappa$ организации самообразовательной подготовки преподавателей гуманитарных дисциплин выстей военной школы в системе непрерывного профессионального образования.

Доказано, что использование кейс-технологии способствует углублению самообразовательной компетентности преподавателей гуманитарных дисциплин за счет выполнения различного рода опережающих заданий (поиск и представление информации в сети Интернет, создание списка ссылок на информачионные ресурсы Интернет, разработка мультимедийной презентации в программе MS Power Point, использование электронной почты, обмен сообщениями в чате, создание и размещчение информачии в блоге и т.д.), способствует активизации исследовательской деятельности преподавателей гуманитарных дисииплин вуза, создает надлежащие условия для практического применения приобретенных знаний при выполнении различного рода задач творческого характера. 
Ключевые слова: самообразовательная підготовка; интерактивные технологи; кейс-технология; новые информационные технологи; портфолио; преподаватели гуманитарных дисциплін; высшие военные учебные заведения.

N.V. Zamotaieva, Senior Lecturer of the Department
for Humanitarian and Social-Economic Training of
Military Training Course of Officer Reserve
at Ivan Chernyakhovskyi National Defense
University of Ukraine (Kyiv city)
REVITALIZING SELF-EDUCATION TRAINING OF HUMANITARIAN
SUBJECTS TEACHERS IN A MILITARY SCHOOL
WITH CASE TECHNOLOGY APPLICATION

The article is devoted to justification of scientific approaches toward the organization of self-education training of humanitarian subjects' teachers in a higher military school as part of continuous professional education.

It has been proven that case technology application contributes to the enhancement of selfeducatory training competence of humanitarian subjects' teachers due to the performance of various kinds of preemptive tasks (search and provision of information on Internet, creating reference list of Internet information resources, development of multimedia presentation in MS Power Point program, using electronic mail, chat message exchange, creation and placement of information in blogs and so on), promotes research activity of humanitarian subjects' teachers at a higher educational establishment, establishes proper environment for practical application of acquired knowledge when performing different kinds of creative tasks.

Key words: self-education training; interactive technologies; case technology; new information technologies; portfolio; humanitarian subjects' teachers; higher military schools. 